\author{
MAEgoRZATA PiECYK \\ Katedra Biotechnologii Mikrobiologii i Oceny Żywności \\ Wydział Nauk o Żywności \\ Szkoła Główna Gospodarstwa Wiejskiego w Warszawie \\ Nowoursynowska 159 C, 02-787 Warszawa \\ E-mail: malgorzata_piecyk@sggw.pl
}

\title{
SKROBIA WOLNO TRAWIONA I SKROBIA OPORNA A INDEKS GLIKEMICZNY PRODUKTÓW SKROBIOWYCH
}

\section{WPROWADZENIE}

Skrobia jest polimerem a-D-glukozy, stanowiącym materiał zapasowy roślin gromadzony $\mathrm{w}$ nasionach, ziarnach i bulwach $\mathrm{w}$ postaci ziarenek, które zbudowane sa $z$ dwóch komponentów różniących się struktura przestrzenną i rozmieszczeniem w ziarenku. Amyloza jest liniowym polimerem a-D-glukozy, której cząsteczki sa połączone wiazaniami a-(1-4)-glikozydowymi. $\quad Z$ kolei amylopektyna jest silnie rozgałęzionym polimerem składającym się $z$ krótkich, prostych łańcuchów a-D-glukozy połączonych wiązaniami a-(1-4)-glikozydowymi, tworzacych szkielet, od którego co 20-25 jednostek glukozy odchodza boczne łańcuchy połączone ze szkieletem wiazaniami a-(1-6) glikozydowymi (PÉREz i BERTOFT 2010). Amylopektyna zazwyczaj stanowi od $70-80 \%$ ziarenka skrobiowego, chociaż skrobie woskowe zbudowane sa praktycznie całkowicie $z$ amylopektyny, a skrobie wysokoamylozowe zawieraja 60-70\% amylozy (TESTER i współaut. 2004). Ziarenka skrobi ogladane pod mikroskopem optycznym wykazuja strukturę warstwowa, która jest wynikiem występowania wokół $h i-$ lum (centrum wzrostu) naprzemiennie pierścieni krystalicznych i amorficznych. Pierścienie krystaliczne skrobi zbudowane sa $z$ helis łańcuchów bocznych amylopektyny, a w pierścieniach amorficznych występuja rozgałęzienia amylopektyny i amyloza (TESTER i współaut. 2004, WANG i COPELAND 2013). Na podstawie analizy ziarenek skrobi pod wpływem promieniowania $\mathrm{X}$ zidentyfikowano trzy typy polimorficzne skrobi, które oznaczono jako typ A, B i C. Różnice pomiędzy nimi spowodowane sa różna długościa łańcuchów amylopektyny w warstwach krystalicznych oraz gęstościa ich upakowania, a także ilościa wody zwiazanej. Struktura polimorficzna typu A jest charakterystyczna dla skrobi większości zbóż (pszenica, kukurydza, ryż), typ B występuje w bulwach, korzeniach i owocach (ziemniaki, banany), natomiast typ C jest charakterystyczny dla skrobi roślin straczkowych i tropikalnych (WANG i współaut. 2013).

Skrobia w diecie człowieka jest głównym źródłem energii pochodzącej $z$ węglowodanów. Zanim w jelicie cienkim nastapi wchłanianie glukozy pochodzacej ze skrobi musi zajść szereg procesów trawiennych. Hydroliza rozpoczyna się $\mathrm{w}$ jamie ustnej pod wpływem obecnej $\mathrm{w}$ ślinie ludzkiej a-amylazy (ptialiny), która w pH 6,0-7,0 hydrolizuje wiazania a-1,4-glikozydowe wewnatrz łańcucha skrobiowego, a produktami rozkładu sa maltoza, maltotrioza i a-dekstryny. Nadtrawiony pokarm trafia do żołądka, w którym czynnikiem odpowiedzialnym za dalszą hydrolize skrobi jest wydzielany przez komórki okładzinowe kwas solny. W niskim $\mathrm{pH}$ soku żołądkowego (około 2,6) następuje inaktywacja a-amylazy ślinowej, ale zachodzi częśsiowa hydroliza kwasowa a-dekstryn. Z żołąka nadtrawiony pokarm przesuwa się do dwunastnicy, gdzie napotka sok trzustkowy, którego wydzielanie jest kontrolowane przez hormony „sytości”. Sok ten zawiera wodoroweglan sodu neutralizujacy kwaśna 
treść docierajaca $z$ żoładka oraz a-amylazę trzustkowa, która hydrolizuje wiazania a-1,4-glikozydowe w skrobi. W jelicie czczym następuje trawienie pod wpływem grupy enzymów soku jelitowego (glukoamylazy, amylo-1,6-glukozydazy, oligo-1,6-glukozydazy i maltazy), które hydrolizuja dekstryny, oligosacharydy i maltoze do glukozy (DoNA i współaut. 2010). Skrobia, która nie uległa hydrolizie, jest fermentowana $\mathrm{w}$ jelicie grubym wskutek aktywności bakterii okrężnicy (WRONKOWSKA i SORAL-SMMIETANA 2006).

W ostatnich latach obserwuje się duże zainteresowanie naukowców trawieniem skrobi. Ma to zwiazek ze stwierdzonymi różnicami w poziomie glukozy we krwi po spożyciu różnych produktów spożywczych zawierających identyczne ilości skrobi (JENKINS i współaut. 1981). Dieta bazujacca na produktach powodujacych gwałtowny wzrost poziomu glukozy we krwi sprzyja rozwojowi chorób dieto-zależnych, takich jak otyłość i cukrzyca typu II (JENKINS i współaut. 2002). Obecnie cukrzyca uznawana jest za chorobe cywilizacyjna, a ze względu na masowość występowania - społeczna (JĘDRZEJEK i SARBINOWSKA 2012). Nowe dane opublikowane przez Światowa Organizację Zdrowia (WHO) wskazuja, że w 2014 r. na świecie żyło 422 mln dorosłych $z$ cukrzyca, co jest wartością około 4-krotnie większą w stosunku do danych z 1980 r. (108 mln) (WHO 2016). Prognozy WHO przewiduja, że w latach 2000-2025 liczba osób chorych na cukrzyce, zwłaszcza typu II, podwoi się. Obecnie rozpowszechnienie cukrzycy sięga w Polsce 9,5\%, natomiast nadwaga, która jest czynnikiem ryzyka choroby, 64\%. Według krajowego profilu cukrzycy choroba ta w Polsce jest przyczyna $2 \%$ wszystkich zgonów.

\section{INDEKS GLIKEMICZNY I METODY JEGO WYZNACZANIA}

Dawniej, przy ustalaniu diety dla diabetyków, produkty spożywcze klasyfikowano na podstawie ilości i rodzaju zawartych $\mathrm{w}$ nich węglowodanów do dwóch głównych grup otrzymując listę produktów zabronionych i dozwolonych. Do pierwszej grupy zaliczano produkty dostarczajace przede wszystkim monosacharydów i sacharozy, a do drugiej zawierające głównie polisacharydy: skrobię i frakcje węglowodanowe błonnika pokarmowego. Ten podział opierał się na założeniu, że mono- i disacharydy sa łatwo przyswajalne i szybko podnosza poziom glukozy we krwi, w zwiazku z tym produkty o dużej ich zawartości powinny być $z$ diety wykluczone. Pod koniec lat 70 . ubiegłego wieku pojawiły się hipotezy, że ten klasyczny podział nie odzwierciedla faktycznych fizjologicznych efektów wywoływanych w organizmie człowieka po spożyciu określonych produktów. Opublikowane przez JENKINSA i współaut. (1981) wyniki badań potwierdzily tę hipotezę, ponieważ autorzy wykazali, że odpowiedź glikemiczna zależy nie tylko od ilości i rodzaju spożywanych węglowodanów, ale także od rodzaju pokarmu. Badania te byly podstawa opracowania koncepcji indeksu glikemicznego (IG) (ENGLYST i współaut. 2007).

Koncepcja IG została uznana przez wiele organizacji i dietetyków, co doprowadziło do dalszych prac, które zaowocowały ustaleniem definicji IG. Według tej definicji jest to stosunek pola pod krzywa glikemiczna otrzymana po podaniu produktu spożywczego zawierajacego $50 \mathrm{~g}$ przyswajalnych metabolicznie węglowodanów, do analogicznego pola otrzymanego po podaniu tej samej ilości węglowodanów $\mathrm{w}$ produkcie standardowym, którym może być glukoza lub biały chleb (FAO/WHO 1998). Pomimo że definicja IG wydaje sie prosta, to ustalenie jego ostatecznej wartości dla produktów jest bardzo trudne ze względu na wiele czynników wpływających na odpowiedź metaboliczna. Wśród nich wymienić można $z$ jednej strony czynniki zwiazane $z$ indywidualnymi cechami osób bioracych udział $\mathrm{w}$ badaniach, $z$ drugiej zaś, te zwiąane ze zmiennościa tempa trawienia skrobi $\mathrm{w}$ zależności od rodzaju produktu (pochodzenie skrobi, stopień przetworzenia produktu). W celu wystandaryzowania warunków wyznaczania IG in vivo Międzynarodowa Organizacja Normalizacyjna opracowała normę ISO 26642:2010 (AUGUSTiN i współaut. 2015). Z kolei zależność strawności i tempa trawienia skrobi od wielu czynników, które zostana omówione w dalszej części, wymusza konieczność wyznaczania wartości IG dla każdego produktu. W zwiazku $z$ tym równolegle do badań dotyczacych wyznaczania IG produktów in vivo obserwuje się intensywny rozwój metod in vitro pozwalających $\mathrm{m}$.in. na określenie $\mathrm{w}$ warunkach laboratoryjnych stopnia strawienia skrobi, szybkości jej hydrolizy, a nawet na wyznaczanie przewidywanego indeksu glikemicznego (pIG).

Bardzo często $\mathrm{w}$ badaniach in vitro do opisu strawności skrobi wykorzystuje się podział zaproponowany przez ENGLYSTA i współaut. (1992). Autorzy ci opracowali warunki hydrolizy skrobi w różnych produktach spożywczych i porównywali je do uzyskanych $\mathrm{w}$ warunkach in vivo, co pozwoliło na stworzenie następujacej klasyfikacji skrobi ze względu na tempo uwalniania glukozy i jej absorpcji w przewodzie pokarmowym: - skrobia szybko trawiona (ang. rapidly digestible starch, RDS), 


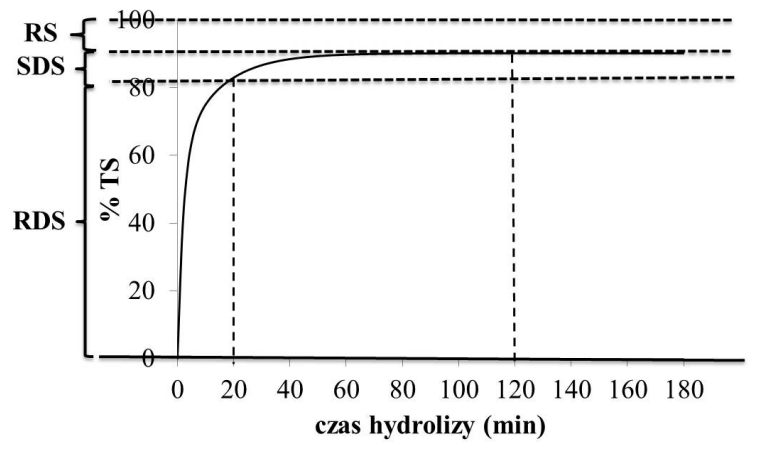

Ryc. 1. Przykładowa krzywa hydrolizy skrobi wyznaczona in vitro.

RDS - skrobia szybko trawiona, SDS - skrobia wolno trawiona, RS - skrobia oporna, TS - skrobia całkowita.

- skrobia wolno trawiona (ang. slowly digestible starch, SDS),

- skrobia oporna (ang. resistant starch, RS).

RDS jest definiowana jako część skrobi zawartej w produkcie, która ulega strawieniu w ciagu $20 \mathrm{~min}$ od spożycia pokarmu i powoduje szybki wzrost poziomu glukozy we krwi. SDS jest to skrobia całkowicie trawiona $\mathrm{w}$ jelicie cienkim, ale $\mathrm{w}$ wolniejszym tempie niż RDS, tj. w czasie 20-120 min od spożycia, zaś RS jest to część skrobi nieulegajaca strawieniu (Ryc. 1).

W ostatnich latach bardzo często $w$ badaniach naukowych strawność skrobi określa się poprzez wyznaczenie udziału RDS, SDS i RS, nawet jeżeli zastosowano inne warunki hydrolizy in vitro niż $\mathrm{w}$ metodzie ENGLYSTA i współaut. (1992), tj. skład mieszaniny enzymów, ich aktywność i czas trawienia, jak np. w metodzie GoNI i współaut. (1997) czy w metodzie 32-40 AACC (AACC 2000). Oczywiście, w tych metodach inne warunki hydrolizy powoduja, że do wyznaczenia RDS, SDS i RS przyjmuje się ilość uwolnionej glukozy po innym czasie niż w metodzie EnGLYSTa i współaut. (1992), wyznaczonym na podstawie porównania krzywych hydrolizy $\mathrm{z}$ wynikami uzyskanymi in vivo.

GONI i współaut. (1997) i GRANFELD i współaut. (1992) opracowali również równania matematyczne do wyznaczania przewidywanego indeksu glikemicznego (pIG) o postaci odpowiednio pIG $=39,71+0,549 \mathrm{IH} \mathrm{i}$ pIG $=8,198+0,862 \cdot \mathrm{IH}$, które często są wykorzystywane $\mathrm{w}$ badaniach naukowych. Do jego obliczenia konieczne jest monitorowanie przez $180 \mathrm{~min}$ przebiegu trawienia skrobi in vitro $\mathrm{w}$ badanym produkcie oraz $\mathrm{w}$ białym chlebie. Krzywe hydrolizy opisuje się równaniem reakcji pierwszego rzędu $\mathrm{C}=\mathrm{C}_{\infty}\left(1 \mathrm{e}^{-}\right.$ $\left.{ }^{k t}\right)$, gdzie $\mathrm{C}$ odpowiada \% hydrolizy skrobi w czasie $t, \mathrm{C}_{\infty}$ to $\%$ hydrolizy skrobi w czasie $\mathrm{t}=180 \mathrm{~min}, \mathrm{a} \mathrm{k}$ to stała kinetyki. Indeks hydrolizy (IH) oblicza się jako stosunek pola powierzchni pod krzywa hydrolizy skrobi w danym produkcie, do pola powierzchni pod krzywa hydrolizy skrobi w chlebie.

Metody in vitro $\mathrm{w}$ badaniach strawności skrobi, w których wyznaczana jest ilość RDS, SDS i RS, sa bardzo często stosowane w badaniach naukowych, chociaż niektórzy badacze zwracaja uwagę, że traktowanie skrobi jako składającej się $z$ kilku frakcji, które trawione sa w różnym tempie jest mylące, gdyż krzywe hydrolizy skrobi moga być opisane tylko jedna reakcja pierwszego rzędu $z$ jedną stałą kinetyki reakcji (BUTTERWORTH i współaut. 2011). Ponadto, nie można otrzymać czystej skrobi opornej czy skrobi wolno trawionej, zawsze frakcje te wspólistnieja, a jedynie moga zmieniać się ich wzajemne proporcje (Ryc. 1) (ZHANG i HAMAKER 2009). Klasyfikacja zaproponowana przez EnGLYSTA i współaut. (1992) nie możne być traktowana dosłownie, a jedynie jako pojęcia umowne pozwalające na ocenę możliwych efektów fizjologicznych w organizmie po spożyciu konkretnego produktu zawierającego skrobię. Wiele badań wykazało, że z żywieniowego punktu widzenia korzystne sa skrobie o wysokim udziale SDS i RS (ENGLYST i ENGLYST 2005), przy czym ich wpływ na organizm jest odmienny.

\section{ZNACZENIE ŻYWIENIOWE SKROBI WOLNO TRAWIONEJ}

Korzyści żywieniowe przypisywane SDS związane sa $z$ wolniejszym poposiłkowym wzrostem stężenia glukozy we krwi i utrzymaniem glikemii na stałym poziomie przez dłuższy czas w porównaniu $z$ RDS, która powoduje szybki wzrost, a następnie szybki spadek glukozy we krwi, często poniżej wartości poczatkowej $\mathrm{w}$ wyniku wysokiego poziomu insuliny (JENKINS i współaut. 2002). Wydłużony czas wchłaniania glukozy po spożyciu produktów bogatych w SDS wpływa na hamowanie uwalniania wolnych kwasów tłuszczowych $z$ tkanki tłuszczowej. Zmniejszenie ich dopływu do watroby sprzyja szybszemu usuwaniu glukozy $z$ układu krażenia i w konsekwencji prowadzi do obniżenia jej stężenia w surowicy (JAROSZ 2010). Te cechy SDS powoduja, że produkty bogate $\mathrm{w}$ te frakcje charakteryzuja niskim indeksem glikemicznym.

Dieta o niskim IG zapobiega hiperinsulinemii, która w przypadku częstego powtarzania się może prowadzić do wyczerpania rezerw trzustkowych i upośledzenia czynności komórek $\beta$, co jest przyczyna cukrzycy typu II, oraz może prowadzić do oporności na insulinę (LuDWIG 2000). Ponadto, dieta 
o wysokim IG powoduje zwiększenie stężenia wolnych kwasów tłuszczowych w surowicy, co z kolei może prowadzić do wzrostu łaknienia, zaburzeń lipidowych i dysfunkcji śródbłonka (BRAND-MILler i MARSH 2008). $\mathrm{Na}$ podstawie analizy wyników licznych badań uważa się, że dieta o niskim IG może zmniejszać ryzyko zachorowania na raka jelita grubego (AUGUSTIN i wspólaut. 2015). Dieta o wysokim IG sprzyja otyłości, co ma zwiazek $z$ wystepowaniem hipoglikemii po spożyciu produktów o wysokim IG. Nagłe zmniejszenie glukozy wywołuje uczucie głodu, które musi być zaspokojone. Zwiększający się odsetek ludzi $z$ nadwaga i otyłościa jest problemem społeczeństwa XXI w. Skutkami otyłości sa takie choroby, jak: choroba niedokrwienna serca, zawał serca, nadciśnienie tętnicze, udar mózgu, cukrzyca, choroby układu oddechowego, zmiany zwyrodnieniowe kości i stawów oraz niektóre nowotwory przewodu pokarmowego (LEBIEDZIŃSKA 2008).

Rozporzadzenie WE 1924/2006 (RozPORZĄDZENIE 2006) wprowadziło możliwość zamieszczania na etykietach produktów spożywczych oświadczeń żywieniowych i zdrowotnych. Oświadczenia zdrowotne to komunikaty, których celem jest poinformowanie konsumenta, że istnieje związek pomiędzy rodzajem żywności, daną żywnościa lub jednym $z$ jej składników a zdrowiem. Na etykietach można zamieszczać te oświadczenia, które zostały zatwierdzone przez Europejski Urząd ds. Bezpieczeństwa Żywności (EFSA) oraz warunkowo oczekujace na rozpatrzenie. Od czasu obowiazywania Rozporzadzenia 1924/2006 EFSA pozytywnie rozpatrzyła wnioski dotyczace 300 oświadczeń zdrowotnych, a ponad 2000 oczekuje na rozpatrzenie. Jednym $z$ wniosków pozytywnie rozpatrzonych był złożony przez przedsiębiorstwo Foods Europe - Biscuits R\&D, należace do grupy Mondelez International, o zatwierdzenie oświadczenia zdrowotnego, zwiąanego $z$ wpływem na zdrowie skrobi wolno trawionej, zawartej w produktach zbożowych. We wniosku przedstawiono wyniki badań zastrzeżonych przez wnioskodawcę, w których porównywano efekty po spożyciu produktów zbożowych bogatych w SDS i produktów o niskiej zawartości SDS, a wysokiej RDS (ROZPORZĄDZENIE 2013). W wyniku pozytywnej weryfikacji przedstawionych dowodów naukowych zostało dopuszczone do stosowania oświadczenie zdrowotne o treści: „spożycie produktów o wysokiej zawartości skrobi wolno trawionej (SDS) podnosi stężenie glukozy we krwi po posiłku w mniejszym stopniu niż spożycie produktów o niskiej zawartości SDS". Oświadczenie może być stosowane wyłącznie w odniesieniu do żywności, w której przyswajalne węlowodany dostarcza- ją co najmniej 60\% całkowitej energii oraz gdy przynajmniej 55\% tych węglowodanów stanowi skrobia przyswajalna, $z$ czego co najmniej $40 \%$ to SDS. Oświadczenie od momentu zatwierdzenia przez okres 5 lat może być stosowane jedynie przez przedsiębiorstwa grupy Mondelez International.

\section{WYSTEPOWANIE I ZNACZENIE ŻYWIENIOWE SKROBI OPORNEJ}

Badania naukowe prowadzone w latach 70. XX w., w których wykazano, że skrobia nie jest całkowicie trawiona $w$ przewodzie pokarmowym człowieka oraz że skrobia niestrawiona wywiera korzystny wpływ na organizm człowieka przyczyniły się do realizacji, w latach 90. ubiegłego wieku, programu pod akronimem EURESTA, finansowanego przez Unię Europejska. W ramach tego projektu ustalono $\mathrm{m}$. in. definicję skrobi opornej, która została określona jako „suma skrobi i produktów jej rozpadu, które nie sa wchłaniane w jelicie cienkim zdrowego człowieka" (AsP i współaut. 1996).

Przyczyny oporności skrobi na trawienie moga być różne i ten fakt był podstawa podziału skrobi opornej na trzy typy (ENGLYST i współaut. 1992). Dalsze badania nad RS wykazały, że oporność na hydrolize może być również efektem modyfikacji skrobi, w zwiazku $z$ tym podzial ten rozszerzono o typ czwarty (LESZCZYŃSKI 2004).

Pierwszy typ skrobi opornej (RS1) to skrobia niedostępna ze względu na występowanie w matrycy utrudniajacej dostęp enzymom trawiennym, np. w niecałkowicie zmielonych ziarnach zbóż czy nasionach roślin straczkowych. Oporność tej skrobi nie jest wynikiem jej specyficznej struktury tylko jej „zamknięciem” w matrycy, a w wyniku zmielenia nasion ilość RS1 znacznie się zmniejsza (SAJILATA i współaut. 2006). Wzbogacanie żywności w RS poprzez dodatek niezmielonych lub ześrutowanych ziaren nie znajduje szerszego zastosowania w żywności ze względu na brak efektów fizjologicznych obserwowanych dla innych typów RS. Drugi typ skrobi opornej (RS2) to nieskleikowane ziarenka skrobi o typie krystalicznym B, które występuja w surowych ziemniakach, niedojrzałych bananach i skrobi wysokoamylozowej. Skleikowanie skrobi ziemniaczanej prowadzi do zaniku oporności na hydrolizę (LESZCZYŃSKI 2004), ale temperatura kleikowania skrobi wysokoamylozowej wynosi powyżej $100^{\circ} \mathrm{C}$, dlatego procesy termiczne poniżej tej temperatury nie powoduja utraty jej oporności. Do produktów spożywczych moga być dodawane preparaty (Hi-maize, Novelose 240) w celu wzbogacenia ich $w$ ten typ RS (SAJILATA i współaut. 2006). Trzeci typ skrobi 
opornej (RS3) powstaje po obróbce hydrotermicznej żywności. Podczas ogrzewania wodnej zawiesiny skrobi ziarenka pęcznieja i, w temperaturze zależnej od jej pochodzenia botanicznego, rozlewaja się, a proces ten nazywany jest kleikowaniem. Podczas tego procesu następuje dysocjacja podwójnych helis (w rejonach krystalicznych), jak również wymywanie amylozy $z$ ziarenka skrobiowego i skrobia przechodzi w stan bezpostaciowy (WANG i CoPEland 2013). Podczas ochładzania kleiku czasteczki skrobi ponownie ulegaja agregacji i powstaja struktury połacczone wiąaniami wodorowymi, w wyniku czego tworzy się żel. Przechowywanie żeli skrobiowych w niskich temperaturach, zwłaszcza bliskich $0^{\circ} \mathrm{C}$, sprzyja dalszym zmianom; następuja przegrupowania wiązań wodorowych pomiędzy łańcuchami skrobi, łańcuchy amylozy łacza się w zwarte micele, a powstajace nowe obszary krystaliczne powoduja zmętnienie kleików. Ponadto, w wyniku zacieśniania struktury żelu woda zwiazana w procesie kleikowania zostaje wypchnięta ze struktury żelu (synereza) (WANG i współaut. 2015). Omówiony proces ponownej krystalizacji skrobi w kleikach nazywany jest retrogradacją i oprócz niekorzystnych zmian, jak synereza, prowadzi również do zmniejszenia strawności skrobi, ponieważ powstajace struktury sa oporne na hydrolizę enzymatyczną (LESZCZYŃSKI 2004). Retrogradacji łatwiej ulega amyloza niż amylopektyna której rozgałęziona struktura utrudnia ponowna asocjację. Oporność na hydrolizę zretrogradowanej skrobi jest wynikiem jej struktury polimorficznej typu B, która jest oporna na wnikanie wody, co jest przyczyna wysokiej termostabilności (WANG i współaut. 2015). $\mathrm{Na}$ rynku dostępne są preparaty RS3, które można dodawać do żywności. Otrzymywane sa $z$ wysokoamylozowej skrobi kukurydzianej, poddawanej cyklom chłodzaco-ogrzewającym (SAJILATA i współaut. 2006).

Ostatnim, czwartym typem skrobi opornej (RS4) jest skrobia, której oporność uzyskuje się w wyniku modyfikacji chemicznych i/lub fizycznych, które powoduja zmiany w strukturze skrobi, mogące ograniczać dostęp enzymów. RS4 może powstawać podczas takich modyfikacji chemicznych skrobi jak: eteryfikacja tlenkiem propylenu (skrobia hydroksypropylowa), estryfikacja bezwodnikiem octowym (skrobia acetylowana) lub utlenienia niektórych grup hydroksylowych (skrobia utleniona) (LESZCZYŃSKI 2004, SAJILATA i współaut. 2006).

Według Rozporzadzenia 1169/2011 (RozPORZĄDZENIE 2011) błonnik pokarmowy „oznacza polimery weglowodanowe $z$ co najmniej trzema jednostkami monomerów, które nie sa trawione ani wchłaniane w jelicie cienkim człowieka", więc zgodnie $z$ tą definicja skrobia oporna jest jego składnikiem. Korzystny wpływ RS na organizm człowieka, podobnie jak innych komponentów błonnika pokarmowego, zwiazany jest $z$ obniżaniem wartości energetycznej produktów (Ryc. 2) (LESZCZYŃSKI 2004), ale najważniejsze efekty fizjologiczne stwierdzone po spożyciu żywności zawierającej RS ( $z$ wyjątkiem RS1) sa wynikiem jej fermentacji $\mathrm{w}$ jelicie grubym przez

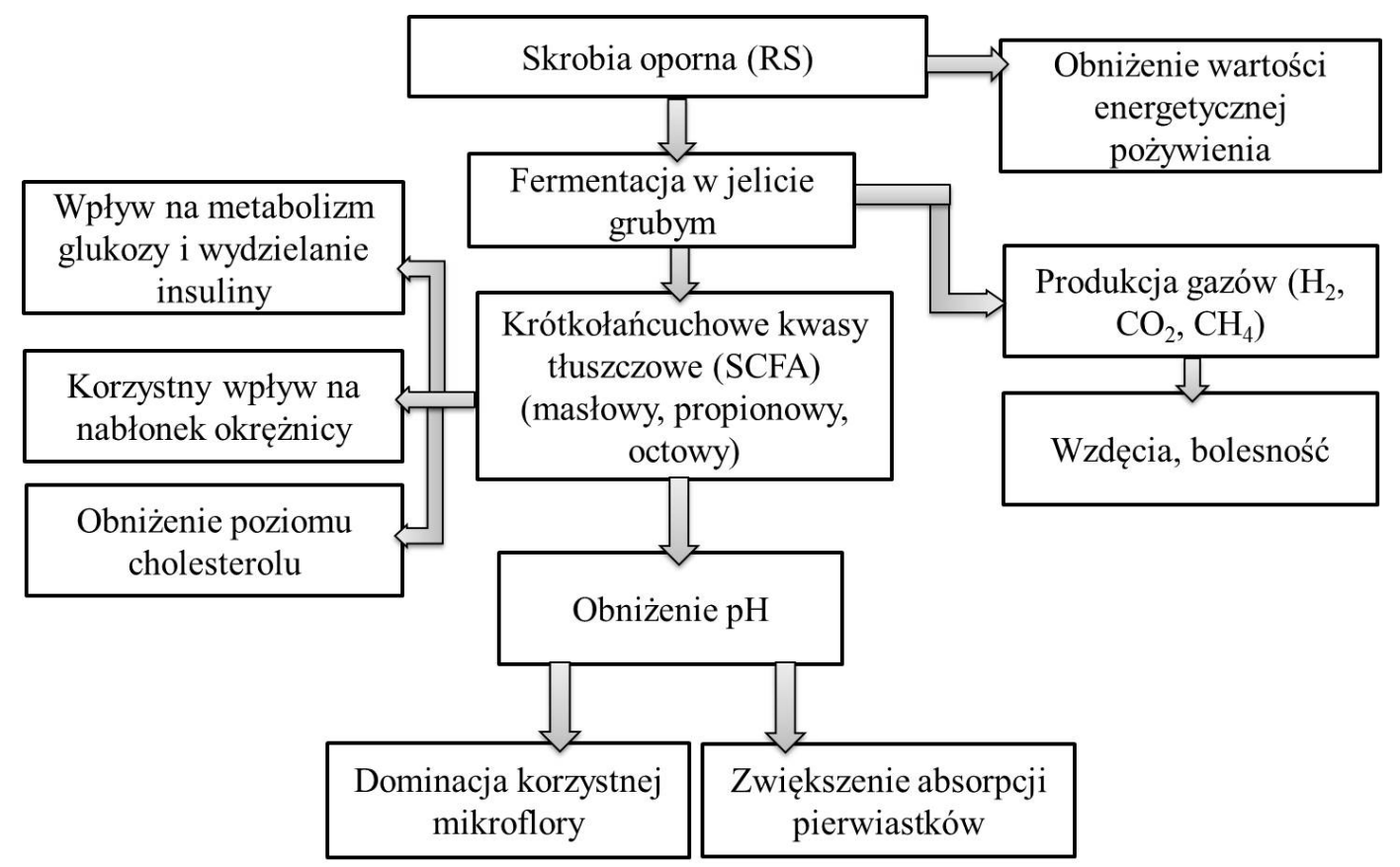

Ryc. 2. Wpływ skrobi opornej na organizm człowieka. 
mikroorganizmy pozytywnie wpływajace na organizm gospodarza. Produktami tego procesu są: metan, wodór i krótkołańcuchowe kwasy tłuszczowe (SCFA), głównie octowy, propionowy i masłowy oraz w mniejszych ilościach walerianowy, izowalerianowy i izomasłowy. W porównaniu $z$ innymi węglowodanami prebiotycznymi, jedynie fermentacji RS towarzyszy wydzielenie znaczących ilości kwasu masłowego (CHAMP i współaut. 2003, MACFARlANE i MACFARLANE 2003). Należy wspomnieć, że w przypadku niektórych osób spożywanie nadmiernych ilości skrobi opornej może mieć negatywne skutki. Powstajace podczas fermentacji gazy moga powodować wzdęcia, kolki, a nawet wodniste biegunki, ale uznano, że korzyści dla organizmu wynikajace ze spożywania RS przewyższaja sporadyczne dolegliwości żołąkkowo-jelitowe (PERERA i współaut. 2010).

Udowodniono, że powstające SCFA maja wieloraki korzystny wpływ na organizm człowieka (Ryc. 2). Obniżenie pH w okrężnicy przez kwasy powstajace podczas fermentacji, zwłaszcza octowy i mlekowy, ogranicza wzrost i rozwój mikroflory patogennej, co prowadzi do dominacji korzystnej mikroflory (WRONKOWSKA i SORAL-ŚMIETANA 2006)

Badania prowadzone na szczurach i ludziach wykazały, że dieta bogata w RS wpływa na zwiększenie przyswajalności pierwiastków takich jak: wapń, magnez, cynk, żelazo czy miedź, co tłumaczone jest obniżaniem pH przez SCFA. W środowisku kwaśnym następuje dysocjacja zwiąków chemicznych i zwiększenie ilości pierwiastków w łatwiej wchłanianej formie jonowej (LOPEZ i współaut. 2001). Z kolei, powstajace podczas fermentacji propioniany maja wpływ na metabolizm lipidów. Obserwowano obniżanie się poziomu cholesterolu i triacylogliceroli pod wpływem propionianów zarówno podawanych doustnie, jak i powstajacych w jelitach (ToDESCO i współaut. 1991). Wśród mechanizmów wyjaśniajacych wpływ propionianów na obniżanie poziomu cholesterolu wskazywana jest inhibicja przez propioniany enzymu bioracego udział w jego syntezie (WRIGHT i współaut. 1990) lub hamowanie powstawania cholesterolu i lipidów $\mathrm{z}$ octanów (DEMigne i współaut. 1995).

Jednym $z$ ważniejszych produktów fermentacji RS jest kwas masłowy, który spełnia ważne funkcje w utrzymaniu odpowiedniego stanu nabłonka okrężnicy i spośród wszystkich SCFA jest najważniejszym źródłem energii dla kolonocytów. Ma wpływ na proliferację komórek nabłonka jelita powodując ich regenerację oraz może indukować apoptozę komórek nowotworowych (KOTUNIA i współaut. 2010). Ponadto stwierdzono, iż kwas masłowy zwiększa poziom przeciwu- tleniacza, glutationu, w błonach śluzowych, chroniac je przed szkodliwym działaniem składników toksycznych (HAMER i współaut. 2009).

RS nie jest węglowodanem przyswajalnym, dlatego podczas badania IG w warunkach in vivo wymagana ilość węglowodanów (50 g) w przygotowanej porcji pokarmu nie może obejmować jej zawartości. Pomimo tego wykazywany jest związek pomiędzy ilościa RS w produkcie a wartościa IG, np. w badaniach chleba $z$ wysokoamylozowa skrobia kukurydziana (RS2) prowadzonych in vivo (BEHALL I HALLFRISCH 2002). Zmniejszenie ilości glukozy we krwi po spożyciu produktów bogatych w RS tłumaczone jest m.in. tym, że powstajace podczas jej fermentacji SCFA wpływaja na metabolizm glukozy i wydzielanie insuliny lub hamuja trawienie skrobi (TODESCO i współaut. 1991, ROBERTsON i współaut. 2005).

Potwierdzone badaniami korzyści zdrowotne dla organizmu, wynikajace ze spożywania skrobi opornej, były podstawa złożenia wniosku do EFSA o zatwierdzenie czterech oświadczeń zdrowotnych (EFSA 2011). Tylko jedno $z$ nich o treści „zastapienie w posiłku skrobi przyswajalnej skrobia oporna pomaga ograniczyć wzrost poziomu glukozy we krwi po tym posiłku", zostało zatwierdzone i opublikowane w Rozporzadzeniu 432/2012. Warunkiem stosowania powyższego oświadczenia jest zastapienie skrobia oporna skrobi przyswajalnej tak, by udział skrobi opornej w całkowitej zawartości skrobi ostatecznie wynosił 14\% (ROZPORZĄDZENIE 2012).

\section{CZYNNIKI WPEYWAJACE NA STRAWNOŚC SKROBI W ŻYWNOŚCI}

Czynniki determinujące strawność i szybkość hydrolizy skrobi były przedmiotem licznych badań, a ich wyniki moga być wykorzystane $\mathrm{w}$ opracowaniu produktów o niskim indeksie glikemicznym i/lub wzbogaconych w skrobię oporną. Strawność skrobi zależy od wielu czynników, które podzielić można na zewnętrzne i wewnętrzne. Czynniki wewnętrzne zwiazane sa $z$ rozmiarem ziarenek skrobiowych i wielkością ich powierzchni oraz $z$ typem polimorficznym struktury skrobi, stosunkiem amylozy do amylopektyny i substancjami zwiazanymi ze skrobia. Z kolei, czynniki zewnętrzne zwiąane sa przede wszystkim ze stopniem przetworzenia żywności i obecnością w niej innych składników.

Czynniki wewnętrzne determinujace strawność skrobi zostały określone na podstawie badań skrobi o różnym pochodzeniu botanicznym. Wykazano $\mathrm{m}$. in., że natywna skrobia zbożowa (typ polimorficzny A) jest 
bardziej podatna na hydrolizę niż skrobia ziemniaczana (typ polimorficzny B) (SRICHUWONG i współaut. 2005). Typy A i B różnią się przede wszystkim upakowaniem podwójnych helis, heksagonalnym $\mathrm{w}$ typie $\mathrm{B}$ $\mathrm{i}$ ortogonalnym w typie A, oraz rozmieszczeniem i ilością cząsteczek wody (większa w typie B niż A) (BUTTERWORTH i współaut. 2011). Mniejsza długość podwójnych helis w łańcuchach bocznych amylopektyny oraz mniejsze różnice w gęstości obszarów krystalicznych i amorficznych w skrobi typu A (ZHANG i współaut. 2006b) powoduja, że jest ona trawiona powoli, ale całkowicie, podczas gdy natywna skrobia typu $B$ trawiona jest w niewielkim stopniu (ENGLYST i współaut. 1992). Strawność skrobi o strukturze będacej mieszanina struktury A i B (typ polimorficzny C), charakterystycznej dla skrobi straczkowej, jest mniejsza niż zbożowej, ale większa niż skrobi ziemniaczanej (HOOVER I ZHOU 2003). Wolne trawienie natywnej skrobi zbożowej było przedmiotem wielu badań mających na celu poznanie determinujących je czynników. Wyjaśnienie tych przyczyn mogłoby być podstawa opracowania metod otrzymywania preparatów skrobi wolno trawionej, które znalazłyby zastosowanie jako składniki żywności. Takie badania prowadzili m. in. SRICHUWONG i współaut. (2005), którzy wykazali, że szybkość hydrolizy a-amylaza ziarenek natywnej skrobi jest skorelowana dodatnio $z$ udziałem łańcuchów amylopektyny o stopniu polimeryzacji (DP) 8-12 i ujemnie $z$ DP 16-26. W innych badaniach wykazano, że również po skleikowaniu kluczowe znaczenie dla tempa trawienia ma struktura amylopektyny, która zależy od pochodzenia botanicznego skrobi i ewentualnych modyfikacji genetycznych (ZHANG i współaut. 2008a). Badania przeprowadzone przez ZHANGA i współaut. (2008b), skrobi z różnych odmian kukurydzy genetycznie modyfikowanej (typ polimorficzny A) wykazały, że najwolniejszym tempem trawienia po skleikowaniu charakteryzowały się te, w których $\mathrm{w}$ amylopektynie występowały łańcuchy albo tylko krótkie, albo tylko długie. Z kolei, bardzo niska strawność natywnej skrobi ziemniaczanej (wysoki udział RS) była podstawa opracowania preparatów RS2, stosowanych w produktach spożywczych jako błonnik pokarmowy (SAJILATA i współaut. 2006).

Strawność skrobi zależy nie tylko od struktury amylopektyny, ale również od średnicy ziarenek i wielkości ich powierzchni. Badania kinetyki hydrolizy skrobi o różnym pochodzeniu botanicznym wykazały, że stosunek powierzchni ziarenka skrobi do jego objętości jest jednym $z$ najważniejszych parametrów określających wielkość obszarów wiązania enzymów oraz ilość dostęp- nych wiązań glikozydowych (DHITAL i współaut. 2010, WARREN i współaut. 2011). Związek między podatnościa skrobi na hydrolizę a wielkością ziarenek zaobserwowano już dawno i tym tłumaczono różnice w strawności skrobi ziemniaczanej i zbożowej (SNOW i O'DEA 1981). Ziarenka skrobi zbożowych są znacznie mniejsze, a ich wielkość mieści się w zakresie 1-40 $\mu \mathrm{m}$, podczas gdy skrobi ziemniaczanej w zakresie 5-100 $\mu \mathrm{m}$ (TESTER i współat. 2004). Takie różnice występuja również pomiędzy skrobiami o tym samym typie polimorficznym. Ziarenka skrobi komosy ryżowej sa bardzo małe (1-2 $\mu \mathrm{m})$ i to powoduje, że skrobia ta zawiera dużo mniej SDS niż skrobia pszenna, pomimo że obie maja strukturę typu A (PIECYK i współaut. 2017). Inne badania w tym zakresie wskazały, że nie można rozpatrywać tylko wielkości ziaren skrobi, jako czynnika warunkującego jej strawność, bez uwzględnienia efektywnej powierzchni obejmującej również pory i kanaliki występujace na jej powierzchni (DHITAL i współaut. 2010). Na podstawie badań prowadzonych w latach 70. XX w. wykazano, że podczas trawienia natywnej skrobi kukurydzianej i pszennej a-amylaza, pewne rejony ziaren były bardziej podatne na hydrolizę niż inne (FuwA i współaut. 1977). Dalsze badania wykazały, że jest to spowodowane występowaniem na powierzchni ziaren skrobiowych małych otworów (porów), które połaczone sa kanalikami $z$ centralna częścią ziarenka. Przez te pory do wnętrza ziarna moga wnikać większe cząsteczki, m. in. enzymy (FANNON i współaut. 1993). W ten sposób zwiększa się powierzchnia wiązania enzymów, w wyniku czego trawienie jest bardziej intensywne. Ziarenka skrobi kukurydzianej, w których stwierdzono obecność porów, sa trawione szybko, natomiast w przypadku ziarenek skrobi ziemniaczanej, enzymy naruszaja jedynie ich powierzchnię, co prowadzi do tworzenia się na niej wgłębień (DHITAL i współaut. 2010). Nie można wykluczyć, że obecność lub brak porów na powierzchni ziarenka zależy od rodzaju warstwy występujacej w tym obszarze. WARREN i współaut. (2011) wykazali, że szybkość wiazania enzymów na powierzchni ziarenka skrobi jest większa, jeśli występuje na niej warstwa amorficzna. Szybsza jest także hydroliza skrobi.

Wśród innych czynników zwiazanych ze struktura skrobi, wpływajacych na jej strawność, w literaturze wymieniany jest stosunek amylozy do amylopektyny. W przypadku badań skrobi natywnej wpływ ten jest niejednoznaczny. Jedne badania wskazuja, iż wyższy udział amylozy wpływa na zmniejszenie strawności (THEMEIER i współaut. 2005), natomiast w innych stwierdzono od- 
wrotna zależność (KAUR i SANDHU 2010). O ile wpływ ilości amylozy na strawność skrobi natywnej jest niejednoznaczny, to w przypadku strawności skrobi po jej uprzednim skleikowaniu jest dobrze poznany i udokumentowany, $i$ jest zwiazany $z$ retrogradacja amylozy. Wśród innych czynników wpływajacych na podatność skrobi na hydrolizę wymienić można obecność innych składników nieskrobiowych $\mathrm{w}$ ziarenkach, $\mathrm{z}$ którymi amyloza może tworzyć kompleksy inkluzyjne, np. z kwasami tłuszczowymi. Badania dowiodły, że działanie amylazy w warunkach in vitro jest mniej skuteczne $\mathrm{w}$ stosunku do kompleksów amylozowo-lipidowych niż to obserwowano w przypadku wolnej amylozy (CUI i OATES 1999). Ważna rolę odgrywa również fosfor występujący $\mathrm{w}$ ziarenkach skrobi w postaci monoestrowej i fosfolipidowej. W skrobi ziemniaczanej występuje głównie $w$ warstwach amorficznych $w$ postaci monoestru fosforanu, utrudniając pęcznienie skrobi i w konsekwencji zmniejszajac jej strawność, natomiast w skrobi pszennej występuje $\mathrm{w}$ postaci fosfolipidów (BLENNOw i współaut. 2000). Strawność natywnej skrobi może również ograniczać białko tworzace zwarta otoczkę na powierzchni ziarenek (BRENNAN i współaut. 1996).

Wszystkie omówione czynniki wpływajace na strawność skrobi zostały określone na podstawie badań skrobi wyizolowanej $z$ surowców i najczęściej nieskleikowanej. W diecie człowieka źródłem skrobi sa przede wszystkim produkty otrzymane $z$ surowców bogatych w skrobię, jak np. ziarna zbóż, poddawanych różnym typom obróbki technologicznej. Ziarenka skrobi w zbożach sa otoczone przez inne struktury, np. ściany komórkowe. Nienaruszona ściana komórkowa stanowi bariere dla enzymów trawiennych (ENGLYST i współaut. 1992), w związku z tym hydroliza skrobi zawartej np. w całych ziarnach zbóż jest bardzo ograniczona. Procesy takie jak mielenie czy kruszenie, niszczące ściany komórkowe i zmniejszajace wielkość cząstek, powodują zwiększenie powierzchni trawienia ułatwiajac ja, co zostało potwierdzone $\mathrm{w}$ badaniach prowadzonych zarówno in vivo, jak $\mathrm{i}$ in vitro (SNOw i O’DEA 1981, WÜRSCH i współaut. 1986). Ponadto, nienaruszone ściany komórkowe, oprócz pełnienia bariery wobec enzymów, ograniczają również wnikanie wody, w wyniku czego skleikowanie skrobi jest mniejsze (BJÖRCK i współaut. 1994). Bardzo dobrym przykładem sa nasiona roślin straczkowych, które zaliczane są w większości opracowań naukowych do żywności o niskim indeksie glikemicznym (oznaczanym in vivo) mieszczacym się, w zależności od obróbki, w zakresie 14-53 (FosTER-POWELl i współaut. 2002).
W zwiąkku z tym, wiele badań poświęcono możliwości wykorzystania ich w żywności przetworzonej w celu obniżenia jej indeksu glikemicznego. Wykazano $\mathrm{m}$. in., że gotowanie maki $z$ nasion o bardzo dużym stopniu rozdrobnienia powoduje, że ilość SDS i RS znacznie się zmniejsza i przewidywany indeks glikemiczny jest bardzo wysoki (PIECYK 2014). Większą ilość SDS i RS oznaczono w makach otrzymanych $z$ nasion ugotowanych i wysuszonych (PIECYK i współaut. 2012), co było spowodowane $\mathrm{m}$. in. tym, że podczas gotowania nasion część skrobi nie uległa skleikowaniu. Ma to znaczenie praktyczne, czego przykładem sa badania MARINANGELI i współaut. (2009), którzy po zastapieniu maki pszennej maka $z$ całych ziaren grochu $\mathrm{w}$ makaronie nie obserwowali istotnych zmian IG. Znaczne zmniejszenie strawności in vitro obserwowano natomiast, gdy makę pszenna zastapiono maka $z$ nasion strączkowych ugotowanych i wysuszonych (GALLEGOS-INFANTE i współaut. 2010).

Wśród zabiegów technologicznych największy wpływ na strawność skrobi ma obróbka hydrotermiczna, która powoduje zniszczenie jej naturalnej struktury semikrystalicznej $\mathrm{w}$ wyniku pękania wewnętrznych i zewnętrznych wiazań wodorowych między łańcuchami skrobi, powodując ich rozdzielenie i otrzymanie skrobi skleikowanej (Dona i współaut. 2010). Stopień skleikowania skrobi jest uzależniony od dostępności wody podczas ogrzewania, temperatury i czasu trwania procesu. Proces kleikowania sprawia, że wiazania glikozydowe staja się bardziej dostępne dla enzymów trawiennych. Potwierdzaja to badania prowadzone już w latach 80. przez Holma i współaut. (1988), którzy wykazali, że podatność skrobi pszennej na działanie a-amylazy trzustkowej była wprost proporcjonalna do stopnia jej skleikowania. Podobne rezultaty otrzymali w badaniach skrobi ziemniaczanej PARADA i AGUilera (2008, 2012), którzy wykazali, że po obróbce termicznej strawność skrobi determinuje stopień skleikowania, a nie wielkość ziarenek skrobi natywnej czy niewielkie różnice w jej strukturze krystalicznej. Dodatkowo, wysoka temperatura powoduje inaktywacje inhibitorów amylaz, które moga znajdować się w produktach, a które hamuja działanie enzymów amylolitycznych (SNow i O’DEA 1981, WÜRSCH i współaut. 1986).

Na strawność skrobi obecnej w żywności, zwłaszcza poddanej różnym typom obróbki termicznej, wpływaja również obecne w niej inne składniki. Wśród nich wymienić można białko, które w przypadku skrobi natywnej, występujac na powierzchni ziarenek, stanowi barierę dla enzymów (WÜRSCH i współaut. 1986, Colonna i współaut. 1992), nato- 
miast po obróbce termicznej kluczowe znaczenie maja interakcje między białkami a skrobią. Wpływ białek na strawność skrobi został potwierdzony $\mathrm{m}$. in. $\mathrm{w}$ badaniach in vivo, w których analizowano poziom glukozy u ludzi po spożyciu chleba $z$ maki pszennej i bezglutenowego $z$ oczyszczonej skrobi pszennej. Stwierdzono, że usunięcie białek wpływało na zwiększenie poziomu glukozy we krwi badanych o 10-20\% (THORNE i współaut. 1983). Badania modelowe in vitro LOPEZ-BARON i współaut. (2017), w których do skrobi pszennej dodawano białka roślinne w postaci zdenaturowanej i/lub zhydrolizowanej i następnie ogrzewano, potwierdziły wystepowanie takich interakcji. Autorzy wykazali, że sa one szczególnie silne w przypadku hydrolizatów białkowych i znaczaco wpływaja na zmniejszenie tempa trawienia skrobi. Uzyskane wyniki wskazują na możliwość zmniejszenia w ten sposób IG produktów bezglutenowych otrzymanych $z$ oczyszczonych skrobi.

Wśród innych składników żywności wpływajacych na tempo trawienia skrobi wymienić można zwiąki zaliczane do rozpuszczalnego błonnika pokarmowego. Składniki te, jak np. pektyny czy $\beta$-glukany, w wyniku wiązania znacznych ilości wody w przewodzie pokarmowym pęcznieja i zwiększaja lepkość treści pokarmowej, co powoduje spowolnienie tempa trawienia skrobi. Potwierdzeniem sa badania zarówno produktów otrzymanych $z$ surowców zawierajacych frakcje rozpuszczalne błonnika i skrobię, np. z owsa (KIM i WHITE, 2012), jak również tych, które wzbogacano w hydrokoloidy, np. gumę guar (DARTOIs i współaut. 2010) czy mieszaninę arabinoksylanów i $\beta$-glukanu (DHITAL i współaut. 2014).

$\mathrm{Na}$ ograniczenie strawności skrobi wpływaja również inne zwiąki zawarte głównie $\mathrm{w}$ nasionach, tj. inhibitory amylaz i fityniany. W produktach poddawanych obróbce termicznej aktywność inhibitorów amylaz jest bardzo mała w wyniku ich inaktywacji. W przypadku fitynianów, związków termostabilnych, ze względu na trwałość wiąania estrowego między kwasem fitynowym a mezo-inozytolem, ich degradacja jest tylko częściowa (ANDERSON i WOLF 1995). Ograniczanie strawności skrobi przez fityniany spowodowane jest wiązaniem przez nie jonów wapnia, które sa aktywatorami enzymów amylolitycznych (Yoon i współaut. 1983).

W ostatnich latach szczególne zainteresowanie naukowców budzi wpływ polifenoli na strawność skrobi. Moga one ja modyfikować w wyniku interakcji ze skrobia oraz poprzez hamowanie aktywności a-amylazy i a-glukozydaz (AMOAKO i AWIKA 2016). Badania wykazały, że interakcje polifenoli ze skrobią moga przyczyniać się do utworzenia kompleksów inkluzyjnych $z$ amyloza lub kompleksu nieinkluzyjnego, w którym siły wiąań sa słabsze (ZHU 2015). Interakcje zależą od masy cząsteczkowej polifenoli, ich hydrofobowości i struktury skrobi. Trwałe kompleksy ze skrobia, zwłaszcza $z$ amyloza, tworza taniny, w wyniku czego zwiększa się ilość RS (AMOAKO i AwIKA 2016). Poprzez odpowiednią kombinację takich czynników jak: typ, skład chemiczny ekstraktu polifenoli (np. z herbaty, winogron), typ polifenoli oraz struktura skrobi i warunki procesu można osiagnać pożądane cechy fizyczne skrobi i żywieniowe (kontrolowane trawienie skrobi i biodostępność polifenoli) (ZHU 2015).

Innym sposobem obniżenia indeksu glikemicznego produktów mogłoby być opracowanie preparatu skrobi o wysokim udziale SDS, który, podobnie jak dostępne komercyjne preparaty RS, mógłby być dodawany do produktów. Największym problemem jest jednak otrzymanie takiej skrobi, która bylaby trawiona wolno, pomimo zastosowanej obróbki hydrotermicznej. Wiele badań poświęcono modyfikacjom skrobi w celu otrzymania preparatow bogatych w termo-stabilną SDS. Wśród nich najbardziej interesujące sa modyfikacje fizyczne i enzymatyczne, ponieważ, zgodnie $z$ oczekiwaniami konsumentów, pozwalaja na zachowanie tzw. „czystej etykiety". Takie skrobie uważane sa za naturalne $i$ nie sa opatrzone symbolem E. Jako przykład można przytoczyć badania modyfikacji skrobi enzymem amylosacharaza. Podczas działania tym enzymem na skrobię w obecności sacharozy następuje wydłużenie końców nieredukujących łańcuchów amylopektyny, co powoduje, że zwiększa się udział SDS i/lub RS (BELLO-PEREZ i współaut. 2018).

\section{PODSUMOWANIE}

W odpowiedzi na potrzeby konsumentów poszukujących produktów łatwych do przygotowania, o długim terminie przydatności do spożycia, producenci skupili się na produkcji żywności wysoko przetworzonej, która mogła zastapić tradycyjny sposób żywienia, bazujacy na pieczywie $z$ maki całoziarnowej, nasionach roślin strączkowych i kaszach. Skutkiem takiej diety jest wzrost zachorowań na choroby dieto-zależne, takie jak cukrzyca typu II czy otyłość. Wyniki badań dowodza, że duży stopień rozdrobnienia surowców skrobiowych i obróbka hydrotermiczna prowadza do zwiększenia indeksu glikemicznego, który ma zwiazek $z$ wymienionymi chorobami. Najlepszym rozwiazaniem jest powrót do diety opartej na produktach nisko przetworzonych, ale nie zawsze jest to 
możliwe. Dotyczy to konsumentów, którzy ze względu na alergię na gluten lub celiakię musza przebywać na diecie bezglutenowej. W takiej diecie często wykorzystywane sa produkty, w których składzie znajduje się oczyszczona skrobia, zazwyczaj pszenna lub ryżowa, co powoduje, że ich IG jest wysoki. Jest to szczególnie niekorzystne, ponieważ często choroba towarzyszaca celiakii jest cukrzyca typu I. Produkty takie można wzbogacać w skrobię oporna oferowaną na rynku. Ponadto, poprzez stosowanie odpowiednich warunków procesów hydrotermicznych podczas obróbki surowców skrobiowych i/lub dodając do produktów składniki modyfikujące strawność skrobi, można skutecznie obniżyć ich IG. Liczne badania nad wpływem różnych modyfikacji na strawność skrobi być może zaowocują w przyszłości opracowaniem preparatu zawierajacego dużo termostabilnej SDS.

\section{Streszczenie}

Stwierdzone różnice $\mathrm{w}$ poziomie glukozy we krwi po spożyciu produktów zawierających identyczne ilości węglowodanów były podstawa powstania koncepcji indeksu glikemicznego (IG). Dieta bazujaca na produktach o wysokim IG sprzyja rozwojowi takich chorób jak otyłość i cukrzyca typu II, dlatego wśród prowadzonych badań szczególną uwagę zwrócono na skrobię - dominujący węglowodan $\mathrm{w}$ diecie człowieka. $\mathrm{W}$ badaniach prowadzonych in vitro, do opisu tempa trawienia skrobi i jej strawności wyznacza się udział skrobi szybko trawionej (RDS), wolno trawionej (SDS) i opornej (RS). RDS jest trawiona $\mathrm{w}$ ciagu $20 \mathrm{~min}$ od spożycia pokarmu powodując szybki wzrost poziomu glukozy we krwi, SDS jest całkowicie trawiona w czasie $20-120$ min od spożycia, zaś RS jest to część skrobi nieulegająca strawieniu. Skrobie o wysokim udziale SDS maja niski IG, a RS sa źródłem błonnika pokarmowego o właściwościach prebiotycznych. Prowadzone liczne badania nad czynnikami wpływajacymi na udział SDS i RS w skrobi moga być podstawa opracowania produktów o niskim IG.

\section{LITERATURA}

AACC, 2000. Approved methods of the AACC. St. Paul, MN.

AMOAKO D., AwIKA J. M., 2016. Polyphenol interaction with food carbohydrates and consequences on availability of dietary glucose. Curr. Opin. Food Sci. 8, 14-18.

ANDERSON R. L., WOLF W. J., 1995. Compositional changes in trypsin inhibitors, phytic acid, saponinns and isoflavones related to soybean processing. J. Nutr. 125, 581S-588S

AsP N. G., VAn Amelsvoort J. M. M., Hautvast J. G. A. J., 1996. Nutritional implications of resistant starch. Nutr. Res. Rev. 9, 1-31.

Augustin L. S., Kendall C. W., Jenkins D. J., WILlETT W. C., ASTRUP A., BARClAY A. W. współaut., 2015. Glycemic index, glycemic load and glycemic response: An international scientific consensus summit from the international carbohydrate quality consortium (ICQC). Nutr. Metab. Cardiovasc. Dis. 25, 795-815.

Behall K. M., Hallfrisch J., 2002. Plasma glucose and insulin reduction after consumption of breads varying in amylose content. Eur $\mathrm{J}$ Clin Nutr. 56, 913-920.

Bello-Perez L. A., Flores-Silva P. C., AGAMA-ACEVEDO E., TOVAR J., 2018. Starch digestibility: past, present, and future. J. Sci. Food Agric., doi.org/10.1002/jsfa.8955.

BJÖRCK I., GRANFELDT Y., LILJEBERG H., TOVAR J., AsP N.G., 1994. Food properties affecting the digestion and absorption of carbohydrates. Am. J. Clin. Nutr. 59 (Suppl.), 699S-705S.

BlenNow A., BAY-SMidT A. M., Olsen C. E., MøLleR B. L., 2000. The distribution of covalently bound phosphate in the starch granule in relation to starch crystallinity. Int. J. Biol. Macromol. 27, 211-218.

BRAND-Miller J., MARSH K., 2008. Dieta o małym indeksie glikemicznym-nowy sposób odżywiania dla wszystkich? Pol. Arch. Med. Wewn. 118, 332-334.

BRENNAN C. S., HARRIS N., SMITH D., SHEWRY P. R., 1996. Structural differences in the mature endosperms of good and poor malting barley cultivars. J. Cereal Sci. 24, 171-177.

ButTERWORTH P. J., WARREN F. J., Ellis P. R., 2011. Human a-amylase and starch digestion: an interesting marriage. Starch-Stärke 63, 395-405.

Champ M., LANGKIlde A. M., Brouns F., Kettlitz B., BAIL-Collet Y. L., 2003. Advances in dietary fibre characterisation. 2. Consumption, chemistry, physiology and measurement of resistant starch; implications for health and food labelling. Nutr. Res. Rev. 16, 143-161

COLONNA P., LELOUP V., BULÉON A., 1992. Limiting factors of starch hydrolysis. Eur. J. Clin. Nutr. 46, S17-S32.

Cui R., OATES C. G., 1999. The effect of amy lose-lipid complex formation on enzyme susceptibility of sago starch. Food Chem. 65, 417-425.

Dartois A., Singh J., KaUR L., Singh H., 2010. Influence of guar gum on the in vitro starch digestibility - rheological and microstructural characteristics. Food Biophys. 5, 149-160.

Demigne C., Morand C., Levrat M. A., Besson C., Moundras C., REMesy C., 1995. Effect of propionate on fatty acid and cholesterol synthesis and acetate metabolism in isolated rat hepatocyte. Br. J. Nutr. 74, 209-219.

DHITAL S., SHREsthA A. K., GIDLEY M. J., 2010. Relationship between granule size and in vitro digestibility of maize and potato starches. Carbohydr. Polym. 82, 480-488.

Dhital S., Dolan G., Stokes J. R., Gidley M. J., 2014. Enzymatic hydrolysis of starch in the presence of cereal soluble fibre polysaccharides. Food Funct. 5, 579-586.

Dona A. C., Pages G. Gilbert R. G., Kuchel P. W., 2010. Digestion of starch: In vivo and in vitro kinetic models used to characterise oligosaccharide or glucose release. Carbohydr. Polym. 80, 599-617.

EFsA, 2011. Scientific Opinion on the substantiation of health claims related to resistant starch and reduction of post-prandial glycaemic responses (ID 681), "digestive health benefits" (ID 682) and "favours a normal colon metabolism" (ID 783) pursuant to Article 13(1): of Regulation (EC) No. 1924/2006. EFSA J. 9, 2024.

Englyst K. N., Englyst H. N., 2005. Carbohydrate bioavailability. Br. J. Nutr. 94, 1-11.

Englyst H. N., Kingman S. M., Cummings J. H., 1992. Classification and measurement of nutritionally important starch fractions. Eur. J. Clin. Nutr. 46, 33-50. 
ENGLYST K. N., LIU S., ENGLYST H. N., 2007. Nutritional characterization and measurement of dietary carbohydrates. Eur. J. Clin. Nutr. 61 (Suppl. 1), S19-S39.

FANNON J. E., Shull J. M., Bemiller J. N., 1993. Interior channels of starch granules. Cereal Chem. 70, 611-613.

FAO/WHO, 1998. Carbohydrates in human nutrition. FAO Corporate Document Repository, 66, 0254-4725.

Foster-POWEll K., Holt S. H., BRAND-MilleR J. C., 2002. International table of glycemic index and glycemic load values: 2002. Am. J. Clin. Nutr. 76, 5-56.

FUWA H., NAKAJIMA M., HAMAdA A., Glover D.V., 1977. Comparative susceptibility to amylases of starches from different plant species and several single endosperm mutants and their double-mutant combinations with opaque-2 inbred Oh43 maize. Cereal Chem. 54, 230-237.

Gallegos-Infante J. A., Bello-Perez L. A., RoCHA-GUZMAN N. E., GONZALEZ-LAREDO R. F., AVILA-ONTIVEROS M., 2010. Effect of the addition of common bean (Phaseolus vulgaris $L$.) flour on the in vitro digestibility of starch and undigestible carbohydrates in spaghetti. J. Food Sci. 75, 151-156.

GONI I., GARCIA-AlONSO A., SAURA-CALIXTO F., 1997. A starch hydrolysis procedure to estimate glycemic index. Nutr. Res. 17, 427-437.

GRANFELDT Y., BJÖRCK I., DREWS A., TOVAR J., 1992. An in vitro procedure based on chewing to predict metabolic responses to starch in cereal and legume products. Eur. J. Clin. Nutr. 46, 649-660.

HAMER H. M., JONKERS D. M., BAST A., VANHOUTVIN S. A., Fischer M. A., Kodde A., TROOST F. J., Venema K., BRUMmer R. J., 2009. Butyrate modulates oxidative stress in the colonic mucosa of healthy human. Clin. Nutr. 28, 88-93.

Holm J., LUNDQUist I., BJÖRCK I., Eliasson A. C. , AsP N. G., 1988. Degree of starch gelatinization, digestion rate of starch in vitro, and metabolic response in rats. Am. J. Clin. Nutr. 47, 1010-1016.

HoOver R., ZHOU Y., 2003. In vitro and in vivo hydrolysis of legume starches by a-amylase and resistant starch formation in legumes - a review. Carbohydr. Polym. 54, 401-417.

JAROSZ M., 2010. Praktyczny podrecznik dietetyki. Instytut Żywności i Żywienia Warszawa.

JEDRZEJEK M., SARBINOWSKA J., 2012. Warsztaty edukacyjne dla pacjentów chorych na cukrzyce-miedzy teoria a praktyka promocji zdrowia. Piel. Zdr. Publ. 3, 213-220.

Jenkins D. J., WOleVer T. M., TAYloR R. H., BARKER H. M., FIELDEN H., BALDWIN J. M., BOWLing A. C., NEWMAN H. C., Jenkins A. L. GoFF D. V., 1981. Glycemic index of foods: a physiological basis for carbohydrate exchange. Am. J. Clin. Nutr. 34, 362-366.

Jenkins D. J., Kendall C. W., Augustin L. S., FRANCESCHI S., HAMIdI M., MARCHIE A., JENKINS A. L., AXELSEN M. AXELSON M., 2002. Glycemic index: overview of implications in health and disease. Am. J. Clin. Nutr. 76, 266-273.

KAUR M., SANDHU K. S., 2010. In vitro digestibility, structural and functional properties of starch from pigeon pea (Cajanus cajan) cultivars grown in India. Food Res. Int. 43, 263268.

KIM J. H., WhITE P. J., 2012. In vitro digestion rate and estimated glycemic index of oat flours from typical and high $\beta$-glucan oat lines. J. Agric. Food Chem. 60, 5237-5242.

Kotunia A., Pietrzak P., Guilloteau P., ZaBielski R., 2010. Kwas masłowy $w$ przewodzie pokarmowym. Prz. Gastroenterol. 5, 117-22.

LEBIEDZIŃSKA A., 2008. Weglowodany $w$ diecie człowieka. Bromat. Chem. Toksykol. 41, 215218.

LESZCZYŃSKI W., 2004. Resistant starch-classification, structure, production. Pol. J. Food Nutr. Sci. 54, 37-50.

LÓPEZ-BARÓN N., GU Y., VASANTHAN T., HOOVER R., 2017. Plant proteins mitigate in vitro wheat starch digestibility. Food Hydrocolloids $69,19-27$

LopeZ H.W., LEVRAT-VERNy M.A., COUdRay C., Besson C., Krespine V., Messager A., DemiGNÉ C., RÉMÉSY C., 2001. Class 2 resistant starches lower plasma and liver lipids and improve mineral retention in rats. J. Nutr. 131, 1283-1289.

LuDWIG D. S., 2000. Dietary glycemic index and obesity. J. Nutr. 130, 280S-283S.

Macfarlane S., Macfarlane G. T., 2003. Regulation of short-chain fatty acid production. Proc. Nutr. Soc. 62, 67-72.

MARINANGELI C. P., KASSIS A. N., JONES P. J., 2009. Glycemic responses and sensory characteristics of whole yellow pea flour added to novel functional foods. J. Food Sci. 74, S385-S389.

PARADA J., Aguilera J. M., 2008. In vitro digestibility and glycemic response of potato starch is related to granule size and degree of gelatinization. J. Food Sci. 74, E34-E38.

PARADA J., AgUILERA J. M., 2012. Effect of native crystalline structure of isolated potato starch on gelatinization behavior and consequently on glycemic response. Food Res. Int. 45, 238243.

Perera A.V. MEdA V., Tyler R.T., 2010. Resistant starch: A review of analytical protocols for determining resistant starch and of factors affecting the resistant starch content of foods. Food Res. Int. 43, 1959-1974.

PÉREZ S., BERTOFT E., 2010. The molecular structures of starch components and their contribution to the architecture of starch granules: A comprehensive review. Starch-Stärke 62, 389420 .

PIECYK M., 2014. Strawność skrobi $w$ mace $z$ nasion roślin straczkowych oraz skrobi wyizolowanej a ich właściwości fizykochemiczne. Rozprawy Naukowe i Monografie, Wydawnictwo SGGW, Warszawa, 454.

PIECYK M., WOŁOSIAK R., DRUŻYŃSKA B., WOROBIEJ E., 2012. Chemical composition and starch digestibility in flour from Polish processed legume seeds. Food Chem. 135, 1057-1064.

PiecyK M., Kowalska K., WorobieJ E., OstrowSKA-LIGEZA E., 2017. Ocena wybranych właściwości skrobi wyizolowanej $z$ nasion komosy ryżowej. Zesz. Probl. Postępów Nauk Rol. 588, 91-102

Robertson M. D., Bickerton A. S., Dennis A. L., VIDAL H., FRAYN K. N., 2005. Insulin sensitizing effects of dietary resistant starch and effects on skeletal muscle and adipose tissue metabolism. Am. J. Clin. Nutr. 82, 559-567.

ROZPORZADZENIE, 2006. Rozporzadzenie (WE) $n r$ 1924/2006 Parlamentu Europejskiego $i$ Rady $z$ dnia 20 grudnia 2006 r. w sprawie oświadczeń żywieniowych $i$ zdrowotnych dotyczacych żywności.

ROZPORZADZENIE, 2011. Rozporzadzenie Parlamentu $i$ Rady (UE) nr 1169/2011 z dnia 25 paź- 
dziernika 2011 r. $w$ sprawie przekazywania konsumentom informacji na temat żywności.

ROZPORZADZZNIE, 2012. Rozporzadzenie Komisji (UE) $n r$ 432/2012 z dnia 16 maja 2012 r. ustanawiajace wykaz dopuszczonych oświadczeń zdrowotnych dotyczacych żywności, innych niż oświadczenia odnoszace sie do zmniejszenia ryzyka choroby oraz rozwoju $i$ zdrowia dzieci.

ROZPORZADZENIE, 2013. Rozporzadzenia Komisji (UE) $n r$ 851/2013 z dnia 3 września 2013 r. dopuszczajace niektóre oświadczenia zdrowotne dotyczace żywności, inne niż oświadczenia odnoszace sie do zmniejszenia ryzyka choroby oraz rozwoju i zdrowia dzieci oraz zmieniajace rozporzadzenie (UE) $n r \quad 432 / 2012$.

Sajilata M. G., Singhal R. S., KulKarni P. R. 2006. Resistant starch - a review. Compr. Rev. Food Sci. Food Saf. 5, 1-17.

SNOW P., O'DEA K., 1981. Factors affecting the rate of hydrolysis of starch in food. Am. J. Clin. Nutr. 34, 2721-2727.

SRICHUWONG S., SUNARTI T. C., Mishima T., IsONO N., Hisamatsu M., 2005. Starches from different botanical sources II: Contribution of amylopectin fine structure to thermal properties and enzyme digestibility. Carbohydr. Polym. 60, 529-538.

TEster R. F., Karkalas J., Yi X., 2004. Starch composition, fine structure and architecture. J. Cereal Sci. 39, 151-165.

Themeier H., HollmanN J., NeEse U., Lindhauer M. G., 2005. Structural and morphological factors influencing the quantification of resistant starch II in starches of different botanical origin. Carbohyd. Polym. 61, 72-79.

THORnE M. J., THOMPSON L. U., Jenkins D. J., 1983. Factors affecting starch digestibility and the glycemic response with special reference to legumes. Am. J. Clin. Nutr. 38, 481-488.

Todesco T., Venketshwer R., BOSEllo O., JenKINS D. J. A., 1991. Propionate lowers blood glucose and alerts lipid metabolism in healthy subjects. Am. J. Clin. Nutr. 54, 860-865.

WANG S., COPELAND L., 2013. Molecular disassembly of starch granules during gelatinization and its effect on starch digestibility: a review. Food Funct. 4, 1564-1580.

Wang S., Li C., Copeland L., NiU Q., Wang S., 2015. Starch retrogradation: A comprehensive review. Compr. Rev. Food Sci. Food Saf. 14, 568-585.

WARREN F. J., Royall P. G., Gaisford S., ButTERWORTH P. J., ElLIS, P. R., 2011. Binding interactions of a-amylase with starch granules: The influence of supramolecular structure and surface area. Carbohydr. Polym. 86, 10381047

WHO, 2016. Global report on diabetes. World Health Organization.

WRIGHT R. S., ANDERSON J. W., BRIDGES S. R., 1990. Propionate inhibits hepatocyte lipid synthesis. Proc. Soc. Exp. Biol. Med. 195, 26-29.

Wronkowska M., Soral-Smietana M., 2006. Skrobia oporna (RS) - struktura, właściwości, funkcje fizjologiczne. Post. Nauk Roln. 6, 103-123.

WÜRSCH P., DEL Vedovo S., KoEllREuTter B., 1986. Cell structure and starch nature as key determinants of the digestion rate of starch in legume. Am. J. Clin. Nutr. 43, 25-29.

YoON J. H., THOMPSON L. U., JENKINS D. J., 1983. The effect of phytic acid on in vitro rate of starch digestibility and blood glucose response. Am. J. Clin. Nutr. 38, 835-842.

ZHANG G., HAMAKER B. R., 2009. Slowly digestible starch: concept, mechanism, and proposed extended glycemic index. Crit. Rev. Food Sci. Nutr. 49, 852-867.

Zhang G., Venkatachalam M., HamakeR B. R. 2006. Structural basis for the slow digestion property of native cereal starch. Biomacromolecules 7, 3259-3266.

Zhang G., Ao Z., HaMAKer B. R., 2008a. Nutritional property of endosperm starches from maize mutants: A parabolic relationship between slowly digestible starch and amylopectin fine structure. J. Agri. Food Chem. 56, 4686-4694.

ZHANG G., SOFYAN M., HAMAKER B. R., 2008b. Slowly digestible state of starch: mechanism of slow digestion property of gelatinized maize starch. J. Agri. Food Chem. 56, 4695-4702.

ZHU F., 2015. Interactions between starch and phenolic compound. Trends Food Sci. Technol. $43,129-143$. 
KOSMOS Vol. 68, 1, 195-207, 2019

\section{MatgorZata Piecyk}

Division of Food Quality Evaluation, Department of Biotechnology, Microbiology and Food Evaluation, Faculty of Food Sciences, University of Life Sciences, 159c Nowoursynowska Str., 02-787 Warszawa, E-mail: malgorzata_piecyk@sggw.pl

\section{SLOWLY DIGESTIBLE STARCH AND RESISTANT STARCH VS. GLYCEMIC INDEX OF STARCHY PRODUCTS}

\section{Summary}

Differences in the level of glucose found in blood after consumption of products containing identical amounts of carbohydrates were the basis for the concept of glycemic index (GI). A diet based on products with a high GI promotes development of diseases such as obesity and type II diabetes. Therefore, in studies special attention was paid to starch - the dominant carbohydrate in a human diet. In vitro studies, to describe the rate of starch digestion and digestibility include determination of the share of rapidly digested starch (RDS), slowly digested starch (SDS) and resistant starch (RS). RDS is digested within 20 minutes after food intake causing a rapid increase in blood glucose, SDS is completely digested during 20-120 minutes after consumption, and RS is a part of starch that is not digestible. Starch with a high SDS share have low GI and RS is a source of dietary fiber with prebiotic properties. Presently conducted numerous studies upon factors affecting relative content of SDS and RS in starch may provide a basis for development of low GI products.

Key words: in vitro starch digestibility, glycemic index, resistant starch, slowly digestible starch 